\title{
New records of disk-winged bats Thyroptera tricolor Spix, 1823 and T. devivoi Gregorin, Gonçalves, Lim \& Engstrom, 2006 (Chiroptera: Thyropteridae) for the Brazilian Amazonia and Cerrado \\ Novo registro de morcegos-de-ventosa Thyroptera tricolor Spix, 1823 e T. devivoi Gregorin, Gonçalves, Lim \& Engstrom, 2006 (Chiroptera: Thyropteridae) para a Amazônia brasileira e Cerrado
}

\author{
Thiago Borges Fernandes Semedo, II (1) | Guilherme Siniciato Terra Garbino III (D) | Natália Ardente ${ }^{\text {IV }}$ (D) \\ Paul François Colas-Rosas ${ }^{\vee}$ (D) Mariene Almeida Torres ${ }^{\text {II }}$ (D) Rogério Vieira Rossill $^{\text {il }}$ \\ Instituto Nacional de Pesquisa do Pantanal/Museu Paraense Emílio Goeldi. Programa de Capacitação Institucional. \\ Cuiabá, Mato Grosso, Brasil \\ "Universidade Federal de Mato Grosso. Pós-Graduação em Zoologia. Cuiabá, Mato Grosso, Brasil \\ "'Universidade Federal de Minas Gerais. Pós-Graduação em Zoologia. Belo Horizonte, Minas Gerais, Brasil \\ IV Universidade do Estado do Rio de Janeiro. Departamento de Ecologia. Rio de Janeiro, Rio de Janeiro, Brasil \\ vBiophilium Consultoria Ambiental. São Paulo, São Paulo, Brasil
}

\begin{abstract}
We present new records for the disk-winged bats Thyroptera tricolor and T. devivoi in central and northern Brazil. Records of T. tricolor are from Aripuanã, Usina Hidrelétrica (UHE) Colíder (both in the northern Mato Grosso state) and Santana do Araguaia (southern Pará state). New records of T. devivoi are from a Cerrado area in the Rio Manso, Rio Quilombo (both in Mato Grosso state) and from an Amazon rainforest area at Juruti (Pará state). The records of Thyroptera devivoi for Pará and Mato Grosso are the first ones for these states and the records from the latter are based on two specimens previously identified as T. discifera. Based on the new identifications, we argue that T. discifera does not occur in the Cerrado.
\end{abstract}

Keywords: Geographic distribution. Mato Grosso. Pará. Range extension.

Resumo: Apresentamos novos registros para as espécies de morcegos Thyroptera tricolor e Thyroptera devivoi no Brasil central e norte. Os registros de T. tricolor são de Aripuanã, Usina Hidrelétrica (UHE) Colíder (ambos no norte do estado do Mato Grosso) e Santana do Araguaia (sul do estado do Pará). Os novos registros de T. devivoi são de área de Cerrado nos rios Manso e Quilombo (ambos no estado do Mato Grosso) e em uma área de floresta amazônica em Juruti (estado do Pará). Estes são os primeiros registros de Thyroptera devivoi para os estados do Pará e Mato Grosso, sendo os registros do Mato Grosso baseados em dois exemplares previamente identificados como T. discifera. Com base na nova identificação, sugerimos que $T$. discifera não ocorre no Cerrado.

Palavras-chave: Distribuição geográfica. Mato Grosso. Pará. Extensão de distribuição.

SEMEDO, T. B. F., G. S. T. GARBINO, N. ARDENTE, P. F. COLAS-ROSAS, M. A. TORRES \& R. V. ROSSI, 2020. New records of disk-winged bats Thyroptera tricolor Spix, 1823 and T. devivoi Gregorin, Gonçalves, Lim \& Engstrom, 2006 (Chiroptera: Thyropteridae) for the Brazilian Amazonia and Cerrado. Boletim do Museu Paraense Emílio Goeldi. Ciências Naturais 15(3): 817-827. DOI: http://doi.org/10.46357/ bcnaturais.v15i3.213.

Autor para correspondência: Thiago Borges Fernandes Semedo. Av. Fernando Corrêa da Costa, 2367. Cuiabá, MT, Brasil. CEP 78060900 (thiagosemedo@gmail.com).

Recebido em 21/11/2019

Aprovado em 21/10/2020

Responsabilidade editorial: Alexandra Maria Ramos Bezerra
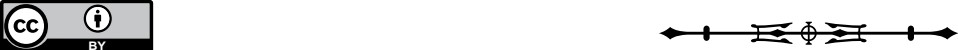


\section{INTRODUCTION}

The genus Thyroptera Spix, 1823 includes five extant species of disk-winged bats: Thyroptera devivoi Gregorin, Gonçalves, Lim \& Engstrom, 2006; Thyroptera discifera (Lichtenstein \& Peters, 1854); Thyroptera lavali Pine, 1993; Thyroptera tricolor Spix, 1823; and Thyroptera wynneae Velazco, Gregorin, Voss \& Simmons, 2014 (Velazco et al., 2014; Lee Jr., 2019). Disk-winged bats are insectivores that usually capture prey directly from the substrate and use foliage as day roost (Dechmann et al., 2006; Wilson, 2008). They inhabit humid lowland forests, including gallery forests in some Neotropical savannas (Gregorin et al., 2006; Tavares \& Mantilla-Meluk, 2015). Four species, T. devivoi, T. discifera, T. lavali, and T. mynneae, are restricted to South America, occurring in savannas and in the Amazonia and Atlantic rainforests (Wilson, 2008; Lee Jr., 2019). The species with the widest range, T. tricolor, occurs in lowland rainforests from southern Mexico to southeastern Brazil (Lee Jr., 2019).

Thyroptera tricolor is distributed in southern Mexico, Central America and South America, where it has been recorded on the island of Trinidad, in Venezuela, Guyana, French Guiana, Surinam, Colombia, Ecuador, Peru, Bolivia, and Brazil (Wilson, 2008; Lee Jr., 2019). In Brazil, it has an apparent disjunct distribution, with records in the Amazonia (Amazonas, Acre, Maranhão, Rondônia, Roraima, and Pará states) and in the Atlantic Forest (Bahia, São Paulo, Paraná, Rio de Janeiro, and Espírito Santo states) (Esbérard et al., 2007; Wilson, 2008; Passos et al., 2010; Castro \& Michalski, 2015; Tavares et al., 2017). It has been reported in sympatry with $T$. discifera and $T$. lavali in several areas within its range of distribution, especially in the Amazonia (Wilson, 2008; Velazco et al., 2014). Thyroptera tricolor commonly roosts in the young rolled leaves of Heliconia (Heliconiaceae) and may occasionally use leaves of other plants as roosts, such as Calathea (Marantaceae), Phenakospermum (Strelitziaceae), and Musa (Musaceae) (Goodwin \& Greenhall, 1961; Wilson \& Findley, 1977; Lee Jr., 2019).
Thyroptera devivoi is known from six localities: one in the Colombian llanos, one in the Guyanan Rupununi savanna, and four in the Brazilian Cerrado (Maranhão, Tocantins, and Piauí states) (Gregorin et al., 2006; Santos, C. et al., 2013; Rodríguez-Posada et al., 2017; Rosa et al., 2020). There is scarce information on the ecology of this recently-described species: one individual from Guyana was captured 'under and eaté palm leaf' (Gregorin et al., 2006); in Colombia, a specimen was caught in a Mauritia flexuosa L. f. grove (Rodríguez-Posada et al., 2017); and in Maranhão state, Brazil, a roosting group was found in a dead palm leaf sheath (Rosa et al., 2020).

In this paper, we present six new records of Thyroptera tricolor and T. devivoi for the southern Brazilian Amazonia, extending the known distribution of both species, and we also comment on the presence of $T$. discifera in the Cerrado.

\section{MATERIALS AND METHODS}

We examined six specimens of Thyroptera preserved as fluid and taxidermied. The specimens are housed in the following institutions: Coleção da Universidade do Estado de Mato Grosso (CZAFMA), campus Alta Floresta, Alta Floresta; Museu Paraense Emílio Goeldi (MPEG), Belém; Museu de Zoologia da Universidade de São Paulo (MZUSP), São Paulo; Universidade Federal de Mato Grosso (UFMT), Cuiabá; Universidade de Brasilia (UNB), Brasília. To identify the specimens, we analyzed qualitative characters of pelage, integument, and dentition based on Gregorin et al. (2006) and Velazco et al. (2014). The external and cranial measurements were taken and are described in the following lines and summarized in Table 1. External measurements were obtained directly from the labels, or were measured by us (GSTG, NA, and PFCR) while preparing the specimens using digital calipers $(0.01 \mathrm{~mm}$ precision), and include: total length $(\mathrm{TL})$ - distance from the tip of the snout to the tip of the last caudal vertebra; length of the tail ( $T$ ) - measured from the point of dorsal flexure of the tail with the sacrum to the tip of the last caudal vertebra;

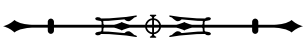


Table 1. External and cranial measurements (in $\mathrm{mm}$ ) and body mass (grams) of Thyroptera devivoi and Thyroptera tricolor. See Material and Methods for abbreviations.

\begin{tabular}{|c|c|c|c|c|c|}
\hline \multirow[b]{2}{*}{ Measurements } & \multicolumn{3}{|c|}{ Thyroptera devivoi } & \multicolumn{2}{|c|}{ Thyroptera tricolor } \\
\hline & UnB 982 & UnB 989 & MPEG 45677 & UFMT 4881 & MZUSP 36011 \\
\hline Sex & Male & Male & Male & Male & Male \\
\hline Age & Adult & Adult & Adult & Sub-adult & Adult \\
\hline W & - & - & 6 & 5 & 3.6 \\
\hline Ear & - & - & 9.97 & 9.62 & 14 \\
\hline FA & 34.99 & 34.27 & 37.6 & 36.91 & - \\
\hline $\mathrm{HF}$ & 6.12 & - & 6.28 & 5.79 & 3 \\
\hline $\mathrm{T}$ & 24.68 & 21.59 & 25.13 & 26.16 & 33 \\
\hline $\mathrm{TL}$ & - & - & 42.58 & 41.14 & 46 \\
\hline GLS & 14.80 & 14.05 & 14.95 & 14.44 & - \\
\hline $\mathrm{CIL}$ & 12.82 & - & 13.92 & 12.51 & - \\
\hline $\mathrm{BB}$ & 6.50 & 6.19 & 6.90 & 6.76 & - \\
\hline $\mathrm{ROL}$ & 4.71 & 5.05 & 5.48 & 4.32 & - \\
\hline ZB & 6.90 & - & 7.82 & 7.57 & - \\
\hline PB & 2.85 & 3.03 & 2.38 & 2.91 & - \\
\hline MTRL & 5.76 & 5.33 & 5.78 & 6.03 & - \\
\hline M3-M3 & 2.66 & 2.12 & 2.98 & 2.62 & - \\
\hline LMA & 10.75 & 9.85 & 10.86 & 10.90 & - \\
\hline MANDL & 5.69 & 5.07 & 5.88 & 4.94 & - \\
\hline
\end{tabular}

hind foot length (HF) - measured from the anterior edge of the base of the calcar to the tip of the claw of the longest toe; ear length (Ear) - measured from the ear notch to the fleshy tip of the pinna; forearm length (FA) - distance from the elbow (tip of the olecranon process) to the wrist (including the carpals, this measurement made with the wing at least partially folded); and mass (W) in grams.

Ten cranial measurements were taken from the specimens using digital calipers $(0.01 \mathrm{~mm}$ precision), followed Velazco et al. (2014) are described as follows: greatest length of the skull (GLS) - distance from the posteriormost point on the occiput to the anteriormost point on the premaxilla (excluding the incisors); condyloincisive length (CIL) - distance between the anteriormost point on the upper incisor and a line connecting the posteriormost margins of the occipital condyles; braincase breadth (BB)
- greatest breadth of the globular part of the braincase, excluding mastoid and paraoccipital processes; rostral length $(\mathrm{ROL})$ - distance from the alveolar process of the premaxilla above the first upper incisor to the ipsilateral postorbital constriction; zygomatic breadth (ZB) - greatest breadth across the zygomatic arches; postorbital breadth (PB) - least breadth at the postorbital constriction; maxillary toothrow length (MTRL) - distance from the anteriormost surface of the upper canine to the posteriormost surface of the crown of M3; width at M3 (M3-M3) - greatest width of palate across labial margins of the M3s; length of the mandible (LMA) - distance from the anteriormost point on the first lower incisor to the posteriormost point on the ipsilateral coronoid process; mandibular toothrow length (MANDL) - distance from the anteriormost surface of the lower canine to the posteriormost surface of M3. 
Thyropterids are easily distinguished from all other Neotropical bats by the presence of a circular adhesive disk on the sole of the foot and an oval or circular disk attached by a short pedicle to the base of the thumb (Figure 1). The species of this genus are characterized by their small size (forearm length between 31 and $41 \mathrm{~mm}$ ); an elongate, slender muzzle; circular and well-separated nares; and funnel-shaped ears. The skull has a rounded braincase elevated above the slender rostrum, with complete premaxillae and no postorbital processes (Wilson, 2008).

To determine the identity of the $T$. devivoi specimens, we observed a bicolored ventral pelage (Figures 1A-1B and 2) (unicolored in T. discifera and T. tricolor, tricolored in T. wynneae), with frosted tips (Figure 1A) (non-frosted in T. lavali), oblong adhesive disks on the thumb (Figure 1C) (circular in T. tricolor and T. discifera), absence of lappets on the calcar (present in the other species or faintly developed in T. devivoi) (Figure 1B); I2 with transversely oriented buccal and labial cusps (obliquely oriented in T. discifera and T. tricolor) (Figures $3 \mathrm{~A}$ and 4 ); and the i3 with twice the buccolingual width of i1 and i2 (Figures 3B and 4) (1.5 times the buccolingual width of $\mathrm{i} 1$ and $\mathrm{i} 2 \mathrm{in} \mathrm{T}$. discifera, $\mathrm{T}$. tricolor, and T. wynneae) (Gregorin et al., 2006; Velazco et al., 2014; Rodríguez-Posada et al., 2017).

The characters used to identify the T. tricolor specimens were: unicolored 'pure white' ventral pelage (Figure 5) (ventral pelage not conspicuously contrasting with dorsum in the other species), circular adhesive disks on the thumb (oblong in T. devivoi, T. lavali, and T. mynneae), calcar with two lappets projecting posterolaterally from the shaft (single lappet in T. discifera and T. lavali, or poorly developed in T. devivoi), and smaller dimension when compared with T. devivoi and T. lavali (Table 1).

\section{RESULTS}

\section{Thyroptera tricolor SPIX, 1823}

The records of Thyroptera tricolor are based on three specimens. The first is from Aripuanã (10 $04^{\prime} 22$ " S,
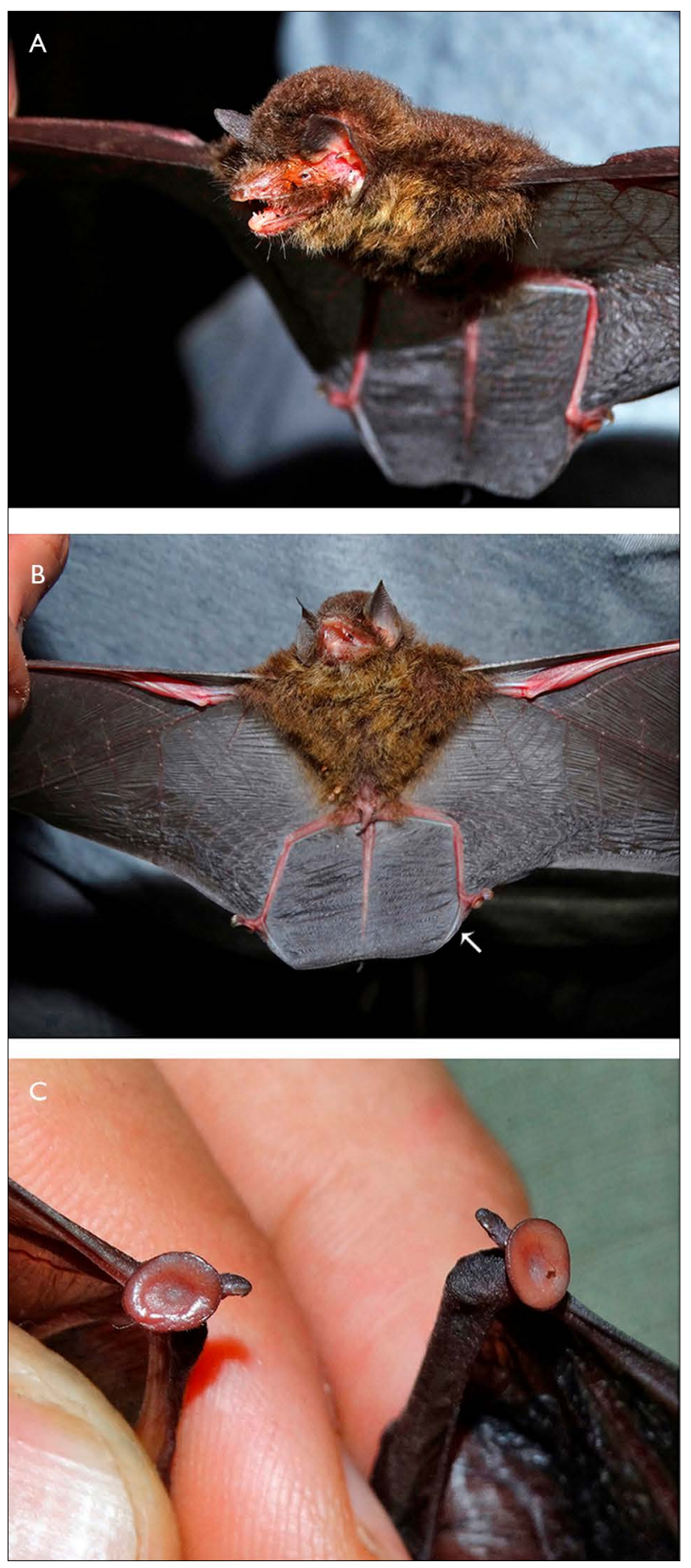

Figure 1. Specimen of Thyroptera devivoi MPEG 45677 collected in Juruti, Pará state, Brazil. Note the frosted ventral pelage (A, B), absence of lappets on the calcaneum (B), and oblong adhesive disks of wing (C). The calcaneum is indicated by a white arrow. Photos: Paul François Colas-Rosas (2015).

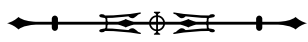


$59^{\circ} 30^{\prime} 41^{\prime \prime}$ W, $\left.175 \mathrm{~m}\right)$, Mato Grosso state, and is a sub-adult male weighing $5 \mathrm{~g}$, captured at $18.30 \mathrm{~h}$ on 29 May, 2019, in a ground-level mist net set across a trail of forested habitat, during the dry season. It is fluid-preserved and had its skull removed, and it is deposited at the Coleção Zoológica da Universidade Federal de Mato Grosso under the collection number UFMT 4881 (Figures 5 and 6). The second specimen of T. tricolor is from Fazenda Fartura in Santana do Araguaia (9०37' 41" S, 50²9' 42" W, $180 \mathrm{~m}$ ), Mato Grosso state. It is an adult male, hand-caught by GSTG while roosting during the day inside a rolled leaf of Heliconia, on 13 April, 2017. The capture area was in a swampy area in a mature lowland Amazon rainforest, approximately 5-8 meters from a dirt road. It is preserved as a taxidermied skin with separated skull and partial skeleton, and it is deposited at the Museu de Zoologia da Universidade de São Paulo (MZUSP 36011). The third specimen of $T$. tricolor was captured at UHE Colíder ( $10^{\circ} 49^{\prime} 08^{\prime \prime}$ S, 55 27' 03" W, 265 m), Pará state. It is a fluid-preserved specimen deposited at the Universidade do Estado de Mato Grosso, campus Alta Floresta, under the collection number CZAF MA 08. The specimen CZAF MA 08 was previously mentioned in a checklist of mammals from Mato Grosso (Brandão et al., 2019), but no locality information was given. These records expand the distribution of T. tricolor in the southern Amazonia, filling a wide gap in the southern part of the distribution of this species in this ecoregion (Figure 7A).

\section{Thyroptera devivoi GREGORIN, GONÇALVES,}

\section{LIM \& ENGSTROM, 2006}

The records of Thyroptera devivoi are based on three specimens. The first specimen is from Rio Manso,

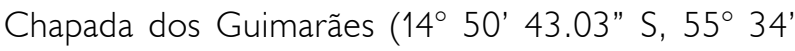
47.30" W, $274 \mathrm{~m}$ ), Mato Grosso state. It is fluidpreserved with the skull removed, and is deposited at the Coleção Zoológica da Universidade de Brasilia under the collection number UnB 982 (Figures 2, 3, 4). The second specimen is from Rio Quilombo, Chapada dos Guimarães

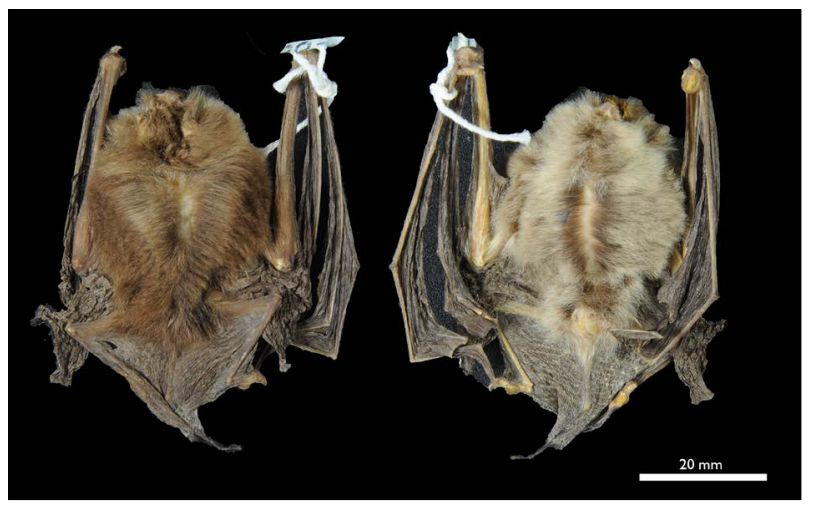

Figure 2. Specimen of Thyroptera devivoi (UnB 982) collected in Rio Manso, Chapada dos Guimarães, Mato Grosso state, Brazil.
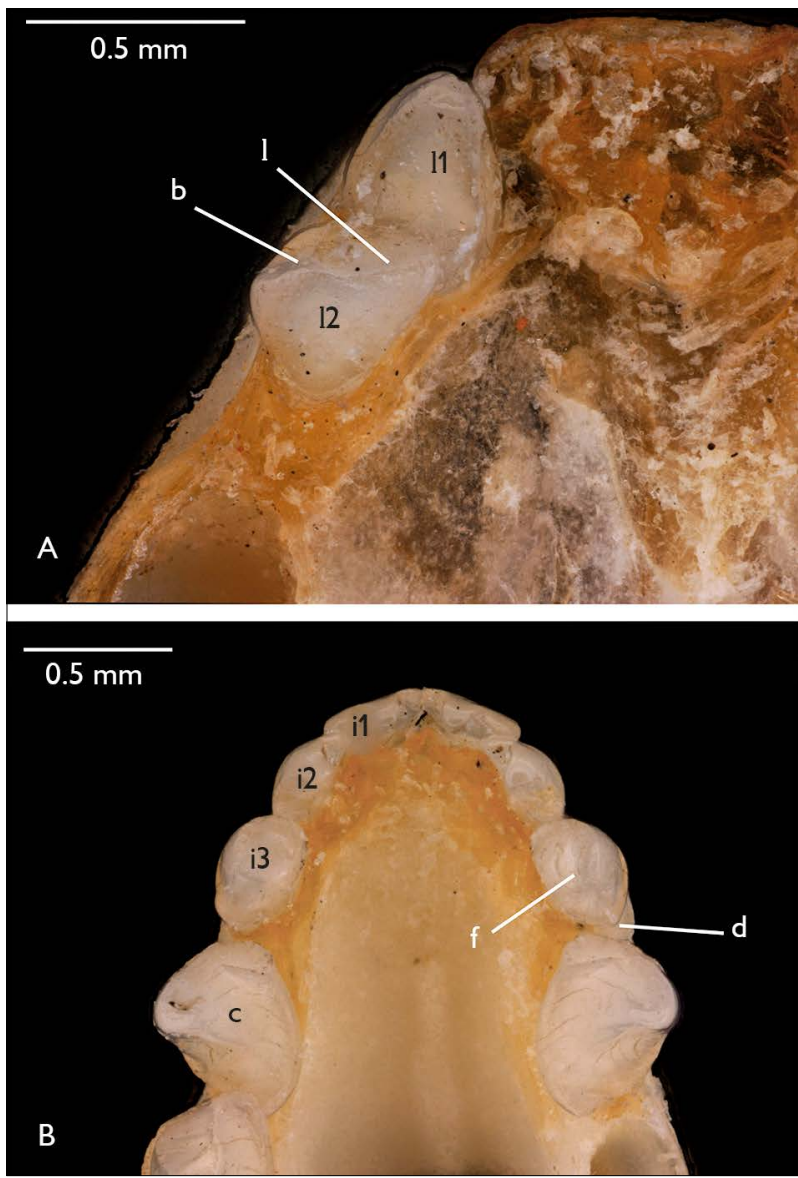

Figure 3. A) Upper incisors, in occlusal view, of Thyroptera devivoi (UnB 982) from Rio Manso, Mato Grosso state, Brazil; B) lower incisors and canine, in occlusal view of the same specimen. Legends: $I 1=$ first upper incisor; 12 = second upper incisor; i1 = first lower incisor; i2 = second lower incisor; $i 3=$ third lower incisor; $c=$ lower canine; $b=$ buccal cusp; $d$ = distostyle; $f=$ fossalike concavity; $l$ = lingual cusp. 


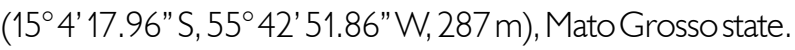
It is fluid-preserved with the skull removed, and deposited at the Coleção Zoológica da Universidade de Brasilia under the collection number UnB 989. Both UnB specimens were previously identified as T. discifera by Bezerra et al. (2005) and considered to be the only known records of the species for the Cerrado. The third record of $T$. devivoi is from Juruti ( $\left.2^{\circ} 15^{\prime} 46.28^{\prime \prime} \mathrm{S}, 56^{\circ} 04^{\prime} 55.51^{\prime \prime} \mathrm{W}, 132 \mathrm{~m}\right)$,
Pará state. It is fluid-preserved and had its skull removed, and it is deposited at the Museu Paraense Emílio Goeldi (MPEG 45677, field number PF 4809). The specimen from Juruti is an adult male, captured with understory mist net in a fragment of mature lowland Amazon rainforest with developed vertical stratification in the dry season. Close to the fragment there are pastures and a railway (Figure 7B).

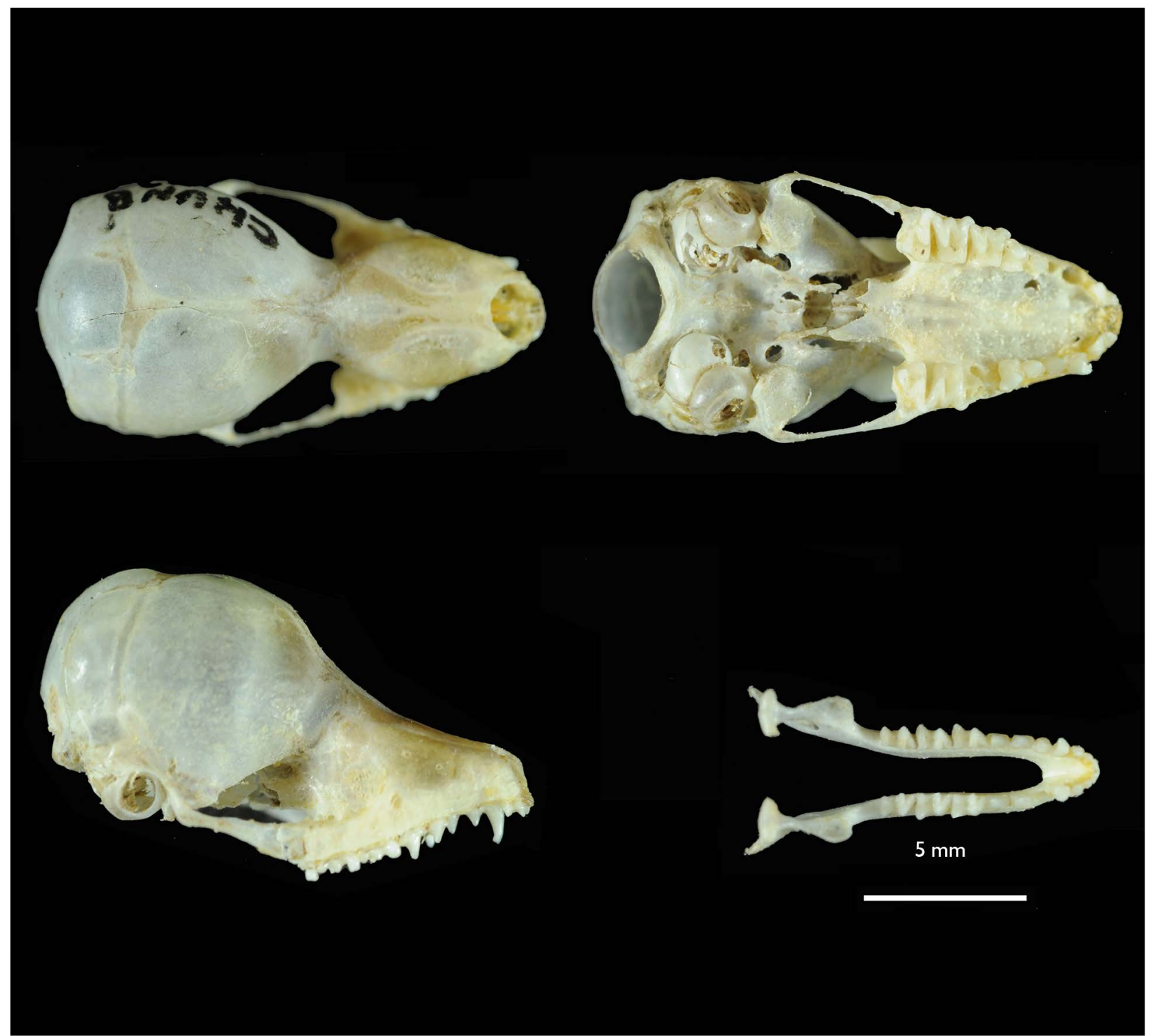

Figure 4. Dorsal, ventral, and lateral views of skull and superior view of mandible of Thyroptera devivoi (UnB 982) collected in Rio Manso, Chapada dos Guimarães, Mato Grosso state, Brazil.

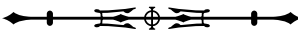




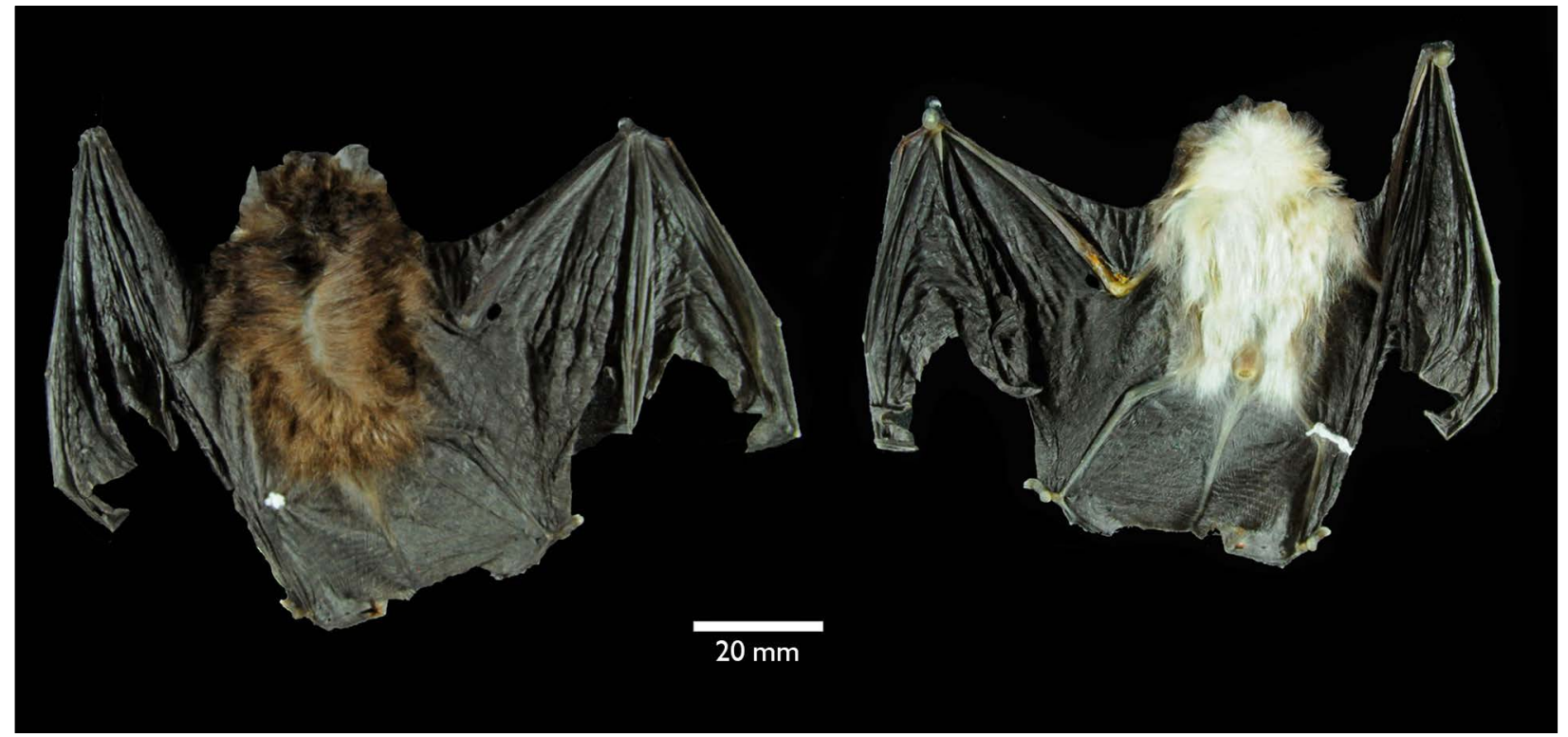

Figure 5. Specimen of Thyroptera tricolor (UFMT 4881) collected in southern Amazonia, Aripuanã, Mato Grosso state, Brazil. Note the pure white ventral fur. Photos: Thiago Semedo (2019).

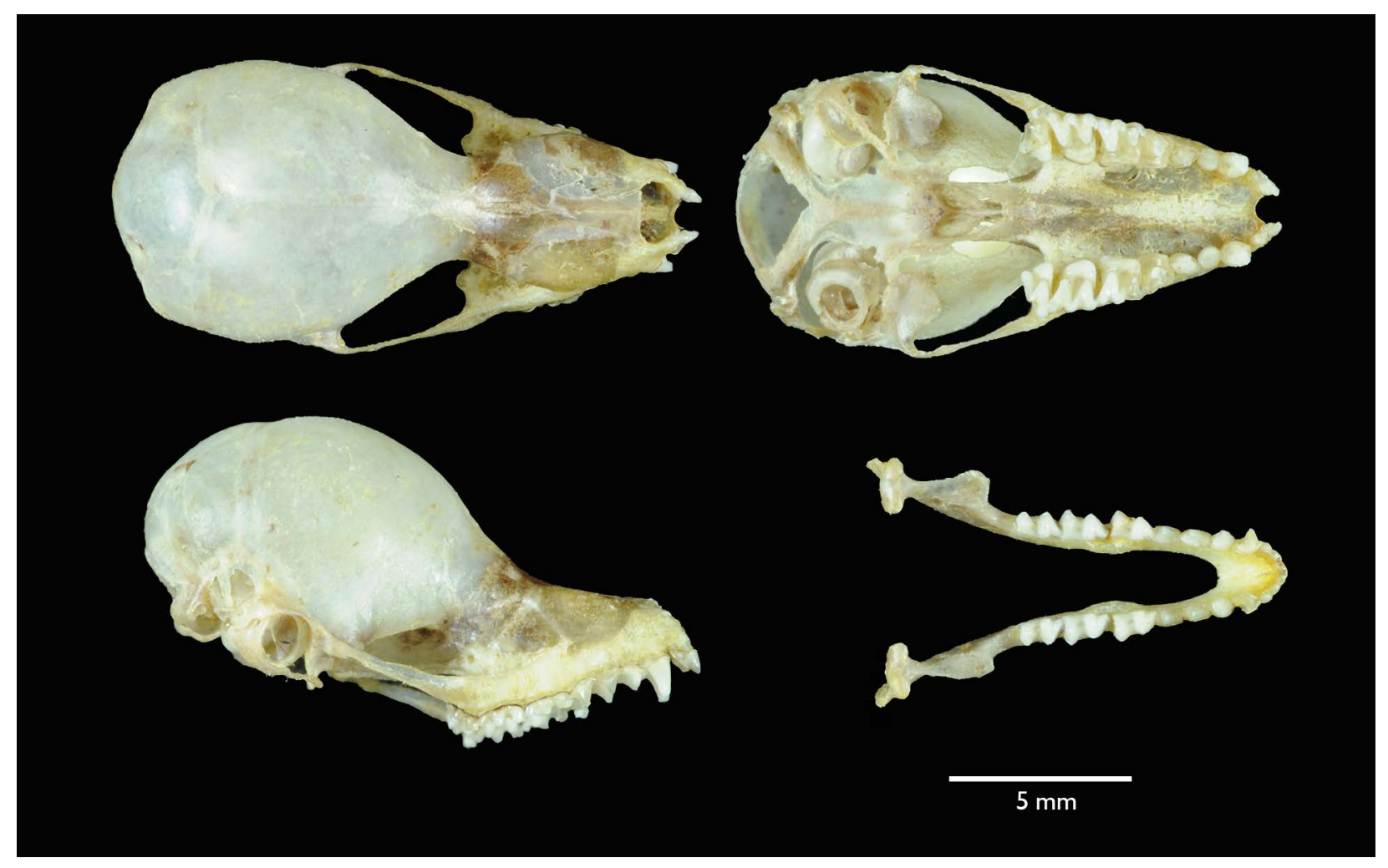

Figure 6. Dorsal, ventral and lateral views of skull of Thyroptera tricolor (UFMT 4881), collected in southern Amazonia, Aripuanã, Mato Grosso state, Brazil.

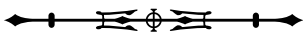



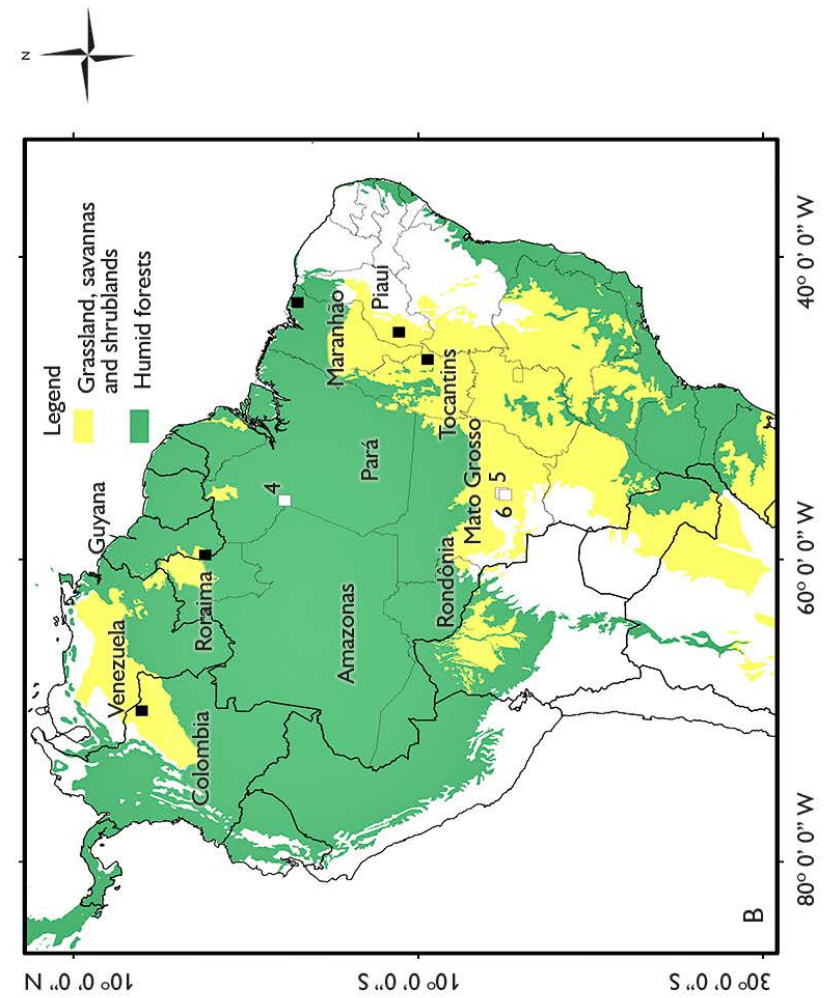

$\mathrm{N}, 0.0 \circ 01$

$\mathrm{S}$ ، $0.0 \circ \mathrm{Ol}$

S ، $0 ، 0$. 0 \&

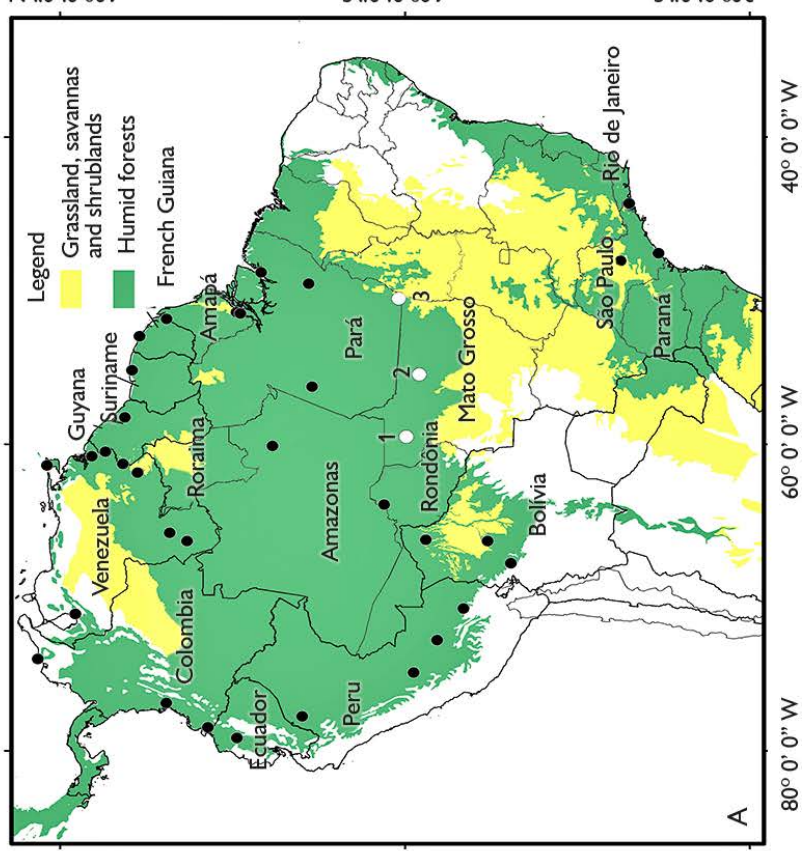

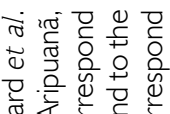

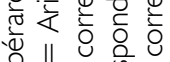

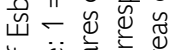

论

ᄃ워

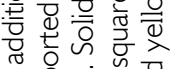

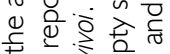

专苍豈

3 过苛

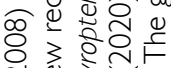

है हो

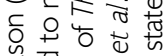

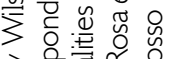

ते 웡해

马

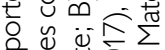

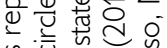

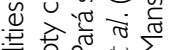

तु है $\widetilde{\mho}^{2}$

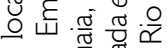

त度

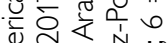

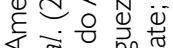

$\approx \widetilde{c}$

专荡焉

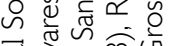

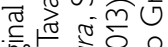

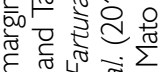

$06 \frac{\pi}{0} \approx$

प्रे

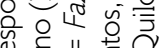

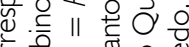

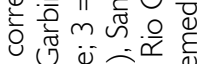

凶.

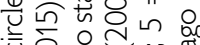

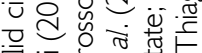

总步芯

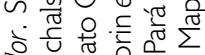

过 $\sum \sum \sum_{0}$

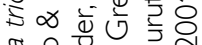

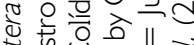

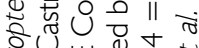

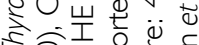

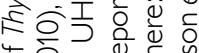

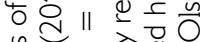

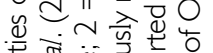

㐘

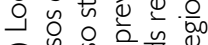

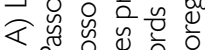

$\therefore$

증원원

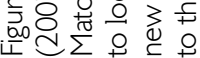

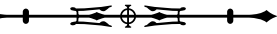




\section{DISCUSSION}

With the verification that the specimens from the Cerrado of Mato Grosso, previously identified as T. discifera by Bezerra et al. (2005), are in fact $T$ devivoi, we suggest that the distribution of $T$. discifera is restricted to the Amazonia and Atlantic Forest (Gregorin et al., 2006; Bocchiglieri et al., 2016). It is important to note, however, that the 'T. discifera' records of Bezerra et al. (2005) were published before the taxonomic reassessment of Thyroptera that resulted in the description of the T. devivoi by Gregorin et al. (2006).

The records of $T$. devivoi are the first for Pará and Mato Grosso states and for southern Amazonia, filling a distribution gap in this biome, as this species was previously reported in the Rupununi savannas, Guyana (Wilson, 2008), approximately $650 \mathrm{~km}$ to the NW from our record in locality 4, Pará state, and our records in localities 5 and 6, Mato Grosso state, are ca. 1,100 to 2,000 km NE from previous records in Maranhão, Piauí, and Tocantins states (Wilson, 2008) (see Figure 7B). The new records extend the distribution of the species southwestward and establish a new southern limit for the taxon (Figure 7B). The records from Mato Grosso are from a 'cerrado' sensu stricto area (i.e. savanna woodland with 10-60\% tree cover), with the occurrence of typical Amazonian taxa, as attested by the presence of the slender mouse opossum Marmosops noctivagus (Tschudi, 1845) (Lacher Jr. \& Alho, 2001) and the Southern Amazon red squirrel Hadrosciurus spadiceus (Olfers, 1818) (Vivo \& Carmignotto, 2015). Our records fit a recent pattern of published range expansions of Amazonian bats for central and southern Amazonia due to increased sampling efforts in these regions and also from review of zoological specimens. Some of these range expansions include records of the molossid Cynomops planirostris (Peters, 1866) (Santos, T. et al., 2015); the emballonurids Centronycteris maximiliani (Fischer, 1829) (Rocha et al., 2015), Peropteryx kappleri Peters, 1867, and Peropteryx leucoptera Peters, 1867 (Dalponte et al., 2016), the vespertilionid Histiotus diaphanopterus Feijó, Rocha \& Althoff, 2015 (Semedo \& Feijó, 2016); and the phyllostomids Glyphonycteris sylvestris (Thomas, 1896), Lonchorhina inusitata Handley \& Ochoa, 1997, Phyllostomus latifolius (Thomas, 1901), Tonatia saurophila Koopman \& Williams, 1951, and Artibeus concolor Peters, 1865 (Miranda et al., 2015; Dalponte et al., 2016).

\section{CONCLUSION}

Our paper clarifies the geographical distributions of T. tricolor and $T$. discifera, the latter which, according to us is restricted to the Amazonia and Atlantic rainforest. We also report a major range extension of $T$. devivoi, highlighting that the distribution of this taxon is still poorly known. The records presented here reinforce the notion, expressed in recent papers, that the large Brazilian states of Mato Grosso and Pará are still under sampled in relation their mammalian diversity, especially regarding small species (Bernard et al., 2011; Brandão et al., 2019). Thyropterids are rare in scientific collections, but we suggest that new records of disk-winged bats will be obtained, and distributional gaps will be filled, as more attention is given to active search in diurnal roosts.

\section{ACKNOWLEDGMENTS}

We are grateful to the following curators and collection managers for allowing access to specimens under their care: Luis Fábio Silveira and Juliana Gualda (MZUSP), José de Souza e Silva Junior and Alexandra Bezerra (MPEG), Jader Marinho-Filho and Pedro De Podestà (UnB), and Mendelson Guerreiro (CZAFMA). We thank SETE Soluções e Tecnologia Ambiental and Nexa companies for the financial support for the fieldwork and for permission for sampling. GSTG is grateful to Luis Fábio Silveira for the opportunity to work in the Fazenda Fartura. We are grateful to Renato Gregorin, Miguel Rodriguez Posada, and Ciro Libio for helping with the identification of Thyroptera species. We are grateful to two anonym reviewers for their valuable suggestions and comments in a previous version of this manuscript. This work was accomplished under the license (Processes 1785/89-IBAMA and 4156/95-46 ACSUPES/DF/IBAMA to NC Ardente). TSBF is supported 
by the Conselho Nacional de Desenvolvimento Cientifico e Tecnológico (CNPq, process number 300659/2019-2) through the Programa de Capacitação Institucional (PCI) of Museu Paraense Emílio Goeldi (MPEG) and Instituto Nacional de Pesquisa do Pantanal (INPP). We thank the Laboratório de Scarabaeoidologia at Universidade Federal de Mato Grosso (Cuiabá, Mato Grosso, Brazil) which provided access to the equipment that we used for the Figure 3, obtained through subproject EECBio of UFMT/FINEP (agreement FINEP \# 01.12.0359.00) and Arturo González who helped us to obtain the photos.

\section{REFERENCES}

BERNARD, E. L., M. S. AGUIAR \& R. B. MACHADO, 2011. Discovering the Brazilian bat fauna: a task for two centuries? Mammal Review 41(1): 23-29. DOI: http://dx.doi.org/10.1111/.13652907.2010.00164.x

BEZERRA, A. M. R., F. ESCARLATE-TAVARES \&J. MARINHO-FILHO, 2005. First record of Thyroptera discifera (Chiroptera: Thyropteridae) in the Cerrado of central Brazil. Acta Chiropterologica 7(1): 165188. DOI: https://doi.org/10.3161/1733-5329(2005)7[165:FROTD C]2.0.CO;2

BOCCHIGLIERI, A., D. S. REIS \& D. M. MELO, 2016. Thyroptera discifera (Lichtenstein \& Peters, 1854) (Chiroptera: Thyropteridae): first record in the state of Sergipe, northeastern Brazil. Check List 12(4): 1-4. DOI: https://doi.org/10.15560/12.4.1940

BRANDÃO, M. B., G. S. T. GARBINO, T. B. F, SEMEDO, A. FEIJÓ, F. O. NASCIMENTO, H. FERNANDES-FERREIRA, R. V. ROSSI, J. DALPONTE \& A. P. CARMIGNOTTO, 2019. Mammals of Mato Grosso, Brazil: annotated species list and historical review. Mastozoología Neotropical 26(2): 263-307. DOI: https://doi. org/10.31687/saremMN.19.26.2.0.03

CASTRO, I. J. \& F. MICHALSKI, 2015. Bats of a varzea forest in the estuary of the Amazon River, state of Amapá, Northern Brazil. Biota Neotropica 15(2): e20140168. DOI: http://dx.doi.org/10.1590/167606032015016814

DALPONTE, J. C., R. GREGORIN, V. A. ESTEVES-COSTA, E. C. ROCHA \& R. MARCELINO, 2016. Bat survey of the lower Juruena River and five new records for the state of Mato Grosso, Brazil. Acta Amazonica 46(2): 227-232. DOI: http://dx.doi.org/10.1590/18094392201500888

DECHMANN, D. K. N., K. SAFI \& M. J. VONHOF, 2006. Matching morphology and diet in the disc-winged bat Thyroptera tricolor (Chiroptera). Journal of Mammalogy 87(5): 1013-1019. DOI: https:// doi.org/10.1644/05-MAMM-A-424R2.1
ESBÉRARD, C. E. L., B. SOARES-SANTOS \& D. FARIA, 2007. New Thryoptera tricolor Spix records in the Atlantic Forest, Brazil (Chiroptera, Thyropteridae). Brazilian Journal of Biology 67(2): 631-637. DOI: http://dx.doi.org/10.1590/S151969842007000200028

GARBINO, G. S. T., 2016. Research on bats (Chiroptera) from the state of São Paulo, southeastern Brazil: annotated species list and bibliographic review. Arquivos de Zoologia 47(3): 43-128. DOI: https://doi.org/10.11606/issn.2176-7793.v47i3p43-128

GOODWIN, G. \& A. M. GREENHALL, 1961. A review of the bats of Trinidad and Tobago: descriptions, rabies infection, and ecology. Bulletin of the American Museum of Natural History 122: 187-302.

GREGORIN, R., E. GONÇALVES, B. K. LIM\& M. D. ENGSTROM, 2006. New species of disk-winged bat Thyroptera and range extension for T. discifera. Journal of Mammalogy 87(2): 238-246. DOI: https://doi.org/10.1644/05-MAMM-A-125R1R1.1

LACHER JR., T. E. \& C. J. R. ALHO, 2001. Terrestrial small mammal richness and habitat associations in an Amazon ForestCerrado contact zone. Biotropica 33(1): 171-181. DOI: https://doi. org/10.1646/0006-3606(2001)033[0171:TSMRAH]2.0.CO;2

LEE JR., T., 2019. Family Thyropteridae (Disk-winged Bats). In: D. E. WILSON \& R. A. MITTERMEIERS (Ed.): Handbook of the mammals of the world: vol. 9: Bats: 418-423. Lynx Edicions, Barcelona.

MIRANDA, J. M., L. ZAGO, F. CARVALHO, M. B. RUBIO \& I. P. BERNARDI, 2015. Morcegos (Mammalia: Chiroptera) da região do Médio Rio Teles Pires, Sul da Amazônia, Brasil. Acta Amazonica 45(1): 89-100. DOI: http://dx.doi.org/10.1590/18094392201400583

OLSON, D. M., E. DINERSTEIN, E. D. WIKRAMANAYAKE, N. D. BURGESS, G. V. N. POWELL, E. C. UNDERWOOD, J. A. D'AMICO, I. ITOUA, H. E. STRAND, J. C. MORRISON, C. J. LOUCKS, T. F. ALLNUTT, T. H. RICKETTS, Y. KURA, J. F. LAMOREUX, W. W. WETTENGEL, P. HEDAO \& K. R. KASSEM, 2001. Terrestrial ecoregions of the World: a new map of life on Earth: a new global map of terrestrial ecoregions provides an innovative tool for conserving biodiversity. BioScience 51(11): 933-938. DOI: https:// doi.org/10.1641/0006-3568(2001)051[0933:TEOTWA]2.0.CO;2

PASSOS, F. C., J. M. MIRANDA, I. P. BERNARDI, N. Y. KAKUOLIVEIRA \& L. C. MUNSTER, 2010. Morcegos da região Sul do Brasil: análise comparativa da riqueza de espécies, novos registros e atualizações nomenclaturais (Mammalia, Chiroptera). Iheringia, Série Zoologia 100(1): 25-34. DOI: http://dx.doi.org/10.1590/ S0073-47212010000100004

ROCHA, P. A., M. V. BRANDÃO, A. C. OLIVEIRA JÚNIOR \& C. C. AIRES, 2015. Range extension of Centronycetris maximiliani (Mammalia: Chiroptera) for southern Amazonia Acta Amazonica 45(4): 425-430. DOI: http://dx.doi.org/10.1590/18094392201501131

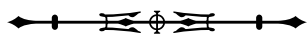


RODRÍGUEZ-POSADA, M., C. FERNÁNDEZ-RODRÍGUEZ, D. MORALES-MARTÍNEZ \& M. CALDERÓN-CAPOTE, 2017. First record of the De Vivo's Disk-winged Bat, Thyroptera devivoi Gregorin, Gonçalves, Lim and Engstrom, 2006 (Chiroptera, Thyropteridae), from Colombia, with comments about the record of Thyroptera lavali Pine, 1993 from the country. Check List 13(4): 355-361. DOI: http://dx.doi.org/10.15560/13.4.355

ROSA, R. O. L., C. H. A. SILVA, T. F. OLIVEIRA, M. SILVEIRA \& L. M. S. AGUIAR, 2020. Type of shelter and first description of the echolocation call of disk-winged bat (Thyroptera devivoi). Biota Neotropica 20(2): e20190821. DOI: https://doi.org/10.1590/16760611-bn-2019-0821

SANTOS, C. L. C., A. C. N. PEREIRA, V. D. J. C. BASTOS, G. GRACIOLLI \& J. M. M. REBÊLO, 2013. Parasitism of ectoparasitic flies on bats in the northern Brazilian cerrado. Acta Parasitologica 58(2): 207-214. DOI: http:dx.doi.org/10.2478/s11686-013-0135-9

SANTOS, T. C. M., G. P. LOPES, A. S. CARVALHO NETO, J. VALSECHI \& A. MARQUEZ-AGUIAR, 2015. New records of Cynomops planirostris (Peters, 1865) (Chiroptera, Molossidae) for the state of Amazonas and its updated distribution in Brazil. Check List 11(6): 1-5. DOI: http://dx.doi.org/10.15560/11.6.1787

SEMEDO, T. B. F. \& A. FEIJÓ, 2016. Filling the gap: first record of the transparent-winged big-eared bat Histiotus diaphanopterus (Chiroptera: Vespertilionidae) in southwestern Brazil. Mammalia 81(3): 323-327. DOI: https://doi.org/10.1515/ mammalia-2016-0007
TAVARES, V. \& H. MANTILLA-MELUK, 2015. Thyroptera tricolor (errata version published in 2016). The IUCN Red List of Threatened Species 2015: e.T21879A97207863. DOI: https:// dx.doi.org/10.2305/IUCN.UK.2015-4.RLTS.T21879A21985559.en

TAVARES, V. D. C., C. C. NOBRE, F. CESAR, E. D. P. NOGUEIRA, J. D. GOMES \& P. E. BOBROWIEC, 2017. The bat fauna from southwestern Brazil and its affinities with the fauna of western Amazon. Acta Chiropterologica 19(1): 93-106. DOI: https://doi. org/10.3161/15081109ACC2017.19.1.007

VELAZCO, P. M., R. GREGORIN, R. S. VOSS \& N. B. SIMMONS, 2014. Extraordinary local diversity of disk-winged bats (Thyropteridae: Thyroptera) in northeastern Peru, with the description of a new species and comments on roosting behavior. American Museum Novitates 2014(3795): 1-29. DOI: https://doi.org/10.1206/3795.1

VIVO, M. \& A. P. CARMIGNOTTO, 2015. Family Sciuridae G. Fischer, 1817. In: J. L. PATTON, U. F. J. PARDIÑAS \& G. D'ELÍA (Eds): Mammals of South America: vol. 2: Rodents: 1-48. The University of Chicago Press, Chicago. DOI: https://doi.org/10.7208/ chicago/9780226169606.001.0001

WILSON, D. \&J. S. FINDLEY, 1977. Thyroptera tricolor. Mammalian Species 71: 1-3. DOI: https://doi.org/10.2307/3503885

WILSON, D., 2008. Family Thyropteridae Miller, 1907. In: A. L. GARDNER (Ed.): Mammals of South America: vol. I: Marsupials, Xenarthrans, Shrews, and Bats: 392-395. The University of Chicago Press, Chicago. 
